\title{
APPLICATION OF ACOUSTIC ANALYSIS IN CONTROL SYSTEMS OF ROBOTIC MACHINE TOOLS
}

Relevance. The problem of controlling complex technological machines such as machines with mechanisms based on kinematics with parallel structure is given consideration in the article in order to improve accuracy of positioning of actuators, to ensure their dynamic adjustment and optimization of trajectories of displacement of operating elements of the equipment (cutting tools, assembling or controlling instruments). The object of the study is the model of the operating area of a mobile robotic machine tool.

Objective. The goal of the work is to create a concept for controlling a mobile robotic machine tool applying acoustic control on the basis of a reference model based on deep neural networks.

Method. A method of identification and control of a mobile robotic machine tool using spectral description of absorption of acoustic wave with further processing of obtained information is offered. This method allows determining accuracy of positioning of actuators, as well as conducting dynamic adjustment and optimization of trajectories of displacement of operating elements of the equipment. A method of acoustic analysis for precision machining on machine tools with parallel kinematics has been developed.

Results. A neural network reference model has been constructed, which allows to diagnose current characteristics of the state of objects in different conditions, namely mechanism's configuration, mechanism's geometric parameters while running motor-spindle, dynamics of displacement of mechanism's nodes of the experimental stand with variable velocities and load on the drive, as well as temperature changes of the object. The developed neural network models also were tested for adequacy.

Conclusions. The experiments on the study of the dependency between the parameters of the spectrum of the acoustic signal with a given discreteness disturbed by excitatory effect in the form of "white noise" confirmed efficiency of this approach. Prospects for further research may consist in creation of methods for optimal control of complex technological machines to improve accuracy of positioning of actuators and to improve their dynamic settings.

Keywords: acoustic diagnostics, robotic machine tool, neural networks, reference model.

\section{NOMENCLATURE}

$\overline{\mathrm{X}}$ - a set characterizing the coordinates $\left\{\mathrm{x}_{\mathrm{i}}, \mathrm{y}_{\mathrm{i}}, \mathrm{z}_{\mathrm{i}}\right\}$ of the object's actuator;

$\bar{Y}$ - a set characterizing the acoustic spectrum of natural oscillations of the object's system;

$\mathrm{A}_{\mathrm{i}}\left(\mathrm{f}_{\mathrm{i}}\right)$ - amplitude of the $k$-th frequency of the amplitude-frequency response;

$\Omega$ - object of modeling;

$\overline{\mathrm{X}}^{\prime}$ - a set of recovered coordinates of the object's actuator;

$\bar{Y}^{\prime}$ - a set of restored characteristics of the acoustic spectrum of natural oscillations of the object's system;

$\mathrm{x}_{\mathrm{i}}, \mathrm{y}_{\mathrm{i}}, \mathrm{z}_{\mathrm{i}}$ - spatial coordinates of the actuator of the object $\Omega$;

$\mathrm{x}_{\mathrm{k}}, \mathrm{y}_{1}, \mathrm{z}_{\mathrm{r}}$ - controlled characteristics of the object;

$\delta$ - error of recovery $\bar{X}$;

$\delta^{\prime}-$ error of recovery $\bar{Y}$;

$\mathrm{W}(\mathrm{f})$ - signal of excitation of the object by the "white noise";

$\mathrm{R}[\mathrm{W}(\mathrm{f})]$ - reaction of the object to the excitatory action $\mathrm{W}(\mathrm{f})$;

$\mathrm{x}_{\mathrm{i}}^{\prime}, \mathrm{y}_{\mathrm{i}}^{\prime}, \mathrm{z}_{\mathrm{i}}^{\prime}$ - restored spatial coordinates of the object's actuator;

$A^{\prime}\left(f_{i}\right)$ - restored amplitude-frequency characteristics;
$\overline{\mathrm{X}}_{1}^{\prime}, \overline{\mathrm{X}_{2}^{\prime}} \ldots-$ a set of identifiers of intermediate layers of deep neural network by $\left\{\mathrm{x}_{\mathrm{i}}, \mathrm{y}_{\mathrm{i}}, \mathrm{z}_{\mathrm{i}}\right\}$;

${\overline{\mathrm{Y}_{1}}}^{\prime},{\overline{\mathrm{Y}_{2}}}^{\prime} \ldots-$ a set of identifiers of intermediate layers of deep neural network by $\left[\mathrm{A}_{\mathrm{i}}\left(\mathrm{f}_{\mathrm{i}}\right)\right]$.

\section{INTRODUCTION}

Perfection of the accuracy and efficiency of mechanical processing technology depends on the quality of control of the actuators of the equipment. Along with increasing technical requirements for actuators, requirements for the control systems of the equipment and processes, in particular for informativeness of the diagnostic channels, are increasing too. In [3, 4, 7, 15, etc.] analysis of the methods and means of analysis of technological equipment and processes of mechanical processing is presented. However, despite a significant progress in creating new tools, methods and means for analysis of objects, topicality of research work in this field is still high [2].

The object of the research is the model of the operating area of a mobile robotic machine tool.

Among actively developing diagnostic methods of objects and processes, it is necessary to allocate the methods of acoustic analysis and creation of control systems on this basis $[5,6,17]$.

The subject of the study is a set of methods for analysis of current characteristics of the state of objects in different conditions, namely mechanism's configuration, mechanism's geometric parameters while running motor- 
spindle, dynamics of displacement of mechanism's nodes of the experimental stand with variable velocities and load on the drive, as well as temperature changes of an object.

The aim of the work is to create a concept for controlling a robotic machine tool using acoustic control on the basis of a reference model based on deep neural networks.

\section{PROBLEM STATEMENT}

Recommendations of work [14] were applied for formalization of mathematical description, in which the spectrum of the signal is represented by spectral characteristics.

In general, these estimates are not dependent and there is a possibility of fluctuations around true value of the spectrum. Using frequency filters with frequency response $S(k)$, modified spectrum $\overline{\mathrm{Y}}$ of the object $\Omega$ is obtained as a function of its properties $\bar{X}$ :

$$
\overline{\mathrm{Y}}=\mathrm{A}_{\mathrm{k}}\left\{\mathrm{f}_{\mathrm{k}}[\mathrm{S}(\mathrm{k})]\right\} \rightarrow \mathrm{F}_{\mathrm{y}}(\overline{\mathrm{X}})
$$

To formulate the problem, the Bayes' theorem [8] was applied. Therefore, two of the main input positions were used: one known, the other one unknown (Fig. 1). The first one is the hypothesis about functional interconnection of frequency response with positioning of the operating element of a robotic machine tool; the other one is statistical data, which, due to transformation of Bayes' theorem, form a posteriori information that has an error within the confidence interval.

The input data is the amplitude-frequency response (obtained due to the measurements carried out by spectral analysis of the acoustic signal in the form of a response to the action of the exciting effect of the "white noise"). Amplitudes of the discrete stages of the obtained amplitude-frequency spectrum are determined by the considerations of the volume of calculations and assumption of a decent error.

Computational model allows determining the coordinates of the actuator of a robotic machine tool and can be used for solving direct and inverse tasks. The direct task is to determine the estimate $\delta$ of the error, so the sum of quadratic deviations of the restored spectral characteristic is minimized within a given error. The inverse task is solved by direct converters, using the neural network constructed for this purpose in reverse order. Then determine inputs for known coordinates $\bar{X}$ and restore initial values $\bar{Y}$ (Fig. 2).

Evaluation of the neural network should not exceed error of recovery $\operatorname{sum}\left(\overline{\mathrm{X}}-\overline{\mathrm{X}}^{\prime}\right)^{2}$

$$
\begin{gathered}
\bar{Y}=F_{x}\left[x_{j}, y_{j}, z_{j}\right], \\
\overline{X^{\prime}}=F_{y}\left[A_{i}\left(f_{i}\right)\right], \\
i=1 . . N, \\
j=1 . . M, \\
M \leq N .
\end{gathered}
$$

When solving the task directly the model is built with unknown data, so the required accuracy is obtained through subsequent training.

In the inverse task, knowing the positioning of the recovered coordinates, training of neural network is performed with subsequent restoration of the frequency response spectrum with subsequent restoration of coordinates, which must differ from the inputs not more than the magnitude of error $\Delta$ (Fig. 3). Therefore, the optimization task is to minimize errors between the input and the reconstructed positioning coordinates.

As the output data, the concept of frequency response is employed (inputs are amplitudes of discrete degrees of frequency response). The number of such degrees is determined by the degree of discretion and is chosen for reasons of volume of calculations, capacity and required accuracy of the model.

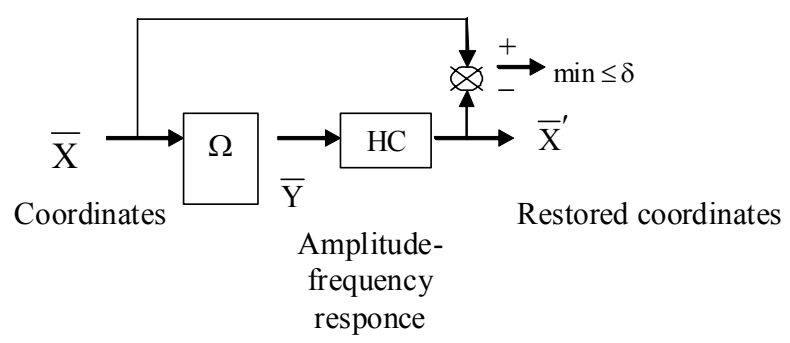

Figure 2 - Concept of neural network model construction

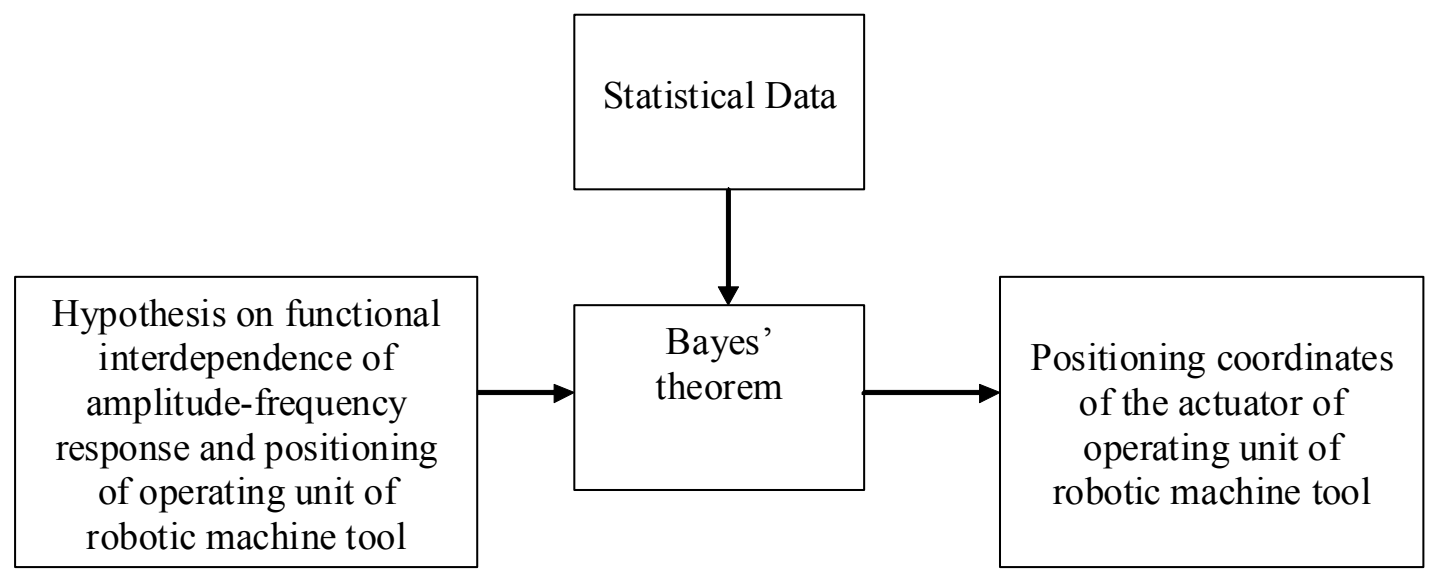

Figure 1 - Representation of the Bayes' approach, taking into account [8] 


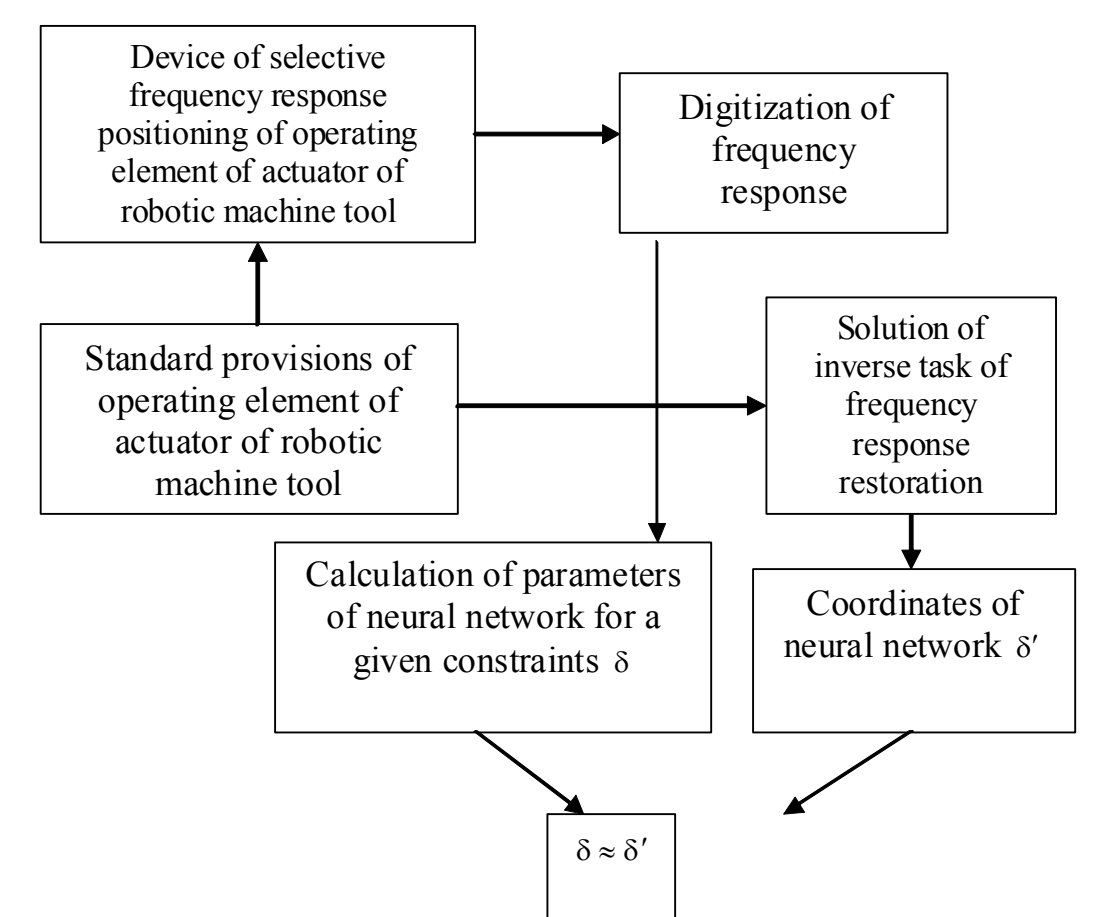

Figure 3 - Information model of the process

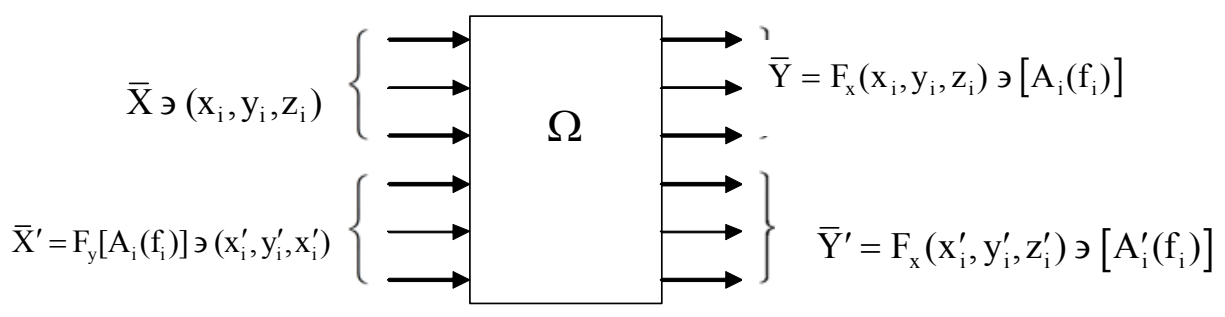

Figure 4 - Modeling of input and recovered coordinates

$$
\begin{gathered}
\bar{X}_{\ni}\left(x_{i}, y_{i}, z_{i}\right) \\
\bar{Y} \ni\left[A_{j}\left(f_{j}\right)\right]=F_{x}\left(x_{i}, y_{i}, z_{i}\right) \\
\bar{X}^{\prime} \ni\left(x_{i}^{\prime}, y_{i}^{\prime}, z_{i}^{\prime}\right)=F_{y}\left[A_{i}\left(f_{i}\right)\right] \\
\bar{Y}^{\prime} \ni\left[A_{i}^{\prime}\left(f_{i}\right)\right]=F_{x}\left[x_{i}^{\prime}, y_{i}^{\prime}, z_{i}^{\prime}\right] \\
\left\{\begin{array}{l}
\sum_{i}^{N}\left[\left(x_{i}-x_{i}^{\prime}\right)^{2}+\left(y_{i}-y_{i}^{\prime}\right)^{2}+\left(z_{i}-z_{i}^{\prime}\right)^{2}\right] \rightarrow \min , \\
M \\
j
\end{array}\left(A_{j}\left(f_{j}\right)-A_{j}^{\prime}\left(f_{j}\right)\right]^{2} \rightarrow \min ,\right. \\
\left|\bar{X}-\bar{X}^{\prime}\right| \leq \delta \\
\left|\bar{Y}-\bar{Y}^{\prime}\right| \leq \delta^{\prime} .
\end{gathered}
$$

For coordinates $\left\{\mathrm{x}_{\mathrm{i}}, \mathrm{y}_{\mathrm{i}}, \mathrm{z}_{\mathrm{i}}\right\}$ restrictions are the following:

$$
\begin{aligned}
& \left|\mathrm{x}_{\mathrm{i}}-\mathrm{x}_{\mathrm{i}}^{\prime}\right| \leq \delta, \\
& \left|\mathrm{y}_{\mathrm{i}}-\mathrm{y}_{\mathrm{i}}^{\prime}\right| \leq \delta, \\
& \left|\mathrm{z}_{\mathrm{i}}-\mathrm{z}_{\mathrm{i}}^{\prime}\right| \leq \delta,
\end{aligned}
$$

Under the terms of recovery of amplitude-frequency response within the limits of error $\delta^{\prime}$ :

$$
\left|A\left(f_{i}\right)-A_{i}^{\prime}(f)\right| \leq \delta^{\prime} .
$$

Each amplitude $A_{i}\left(f_{i}\right)$ is endowed by distribution of probabilistic characteristics. For a given input $\mathrm{X}$ neural network restores value Y. For a given frequency response specimen a computational model has been created, which allows accurate $\left|\overline{\mathrm{X}}-\overline{\mathrm{X}^{\prime}}\right| \leq \delta$ recovery $\overline{\mathrm{Y}^{\prime}}=\mathrm{F}_{\mathrm{x}}\left[\mathrm{x}_{\mathrm{i}}^{\prime}, \mathrm{y}_{\mathrm{i}}^{\prime}, \mathrm{z}_{\mathrm{i}}^{\prime}\right]$ (Fig. 4). For this purpose an optimization task is solved, which contains a target function and has limitations.

\section{LITERATURE REVIEW}

In $[6,17]$ authors consider issues related to the analysis of technological equipment. The main task of analysis is to recognize the state of the object in conditions of limited information [1]. The algorithm of recognition is partly based on diagnostic models, which establish relationship between the states of the objects and their reflections in space of assessed indications [18].

Authors [9, 10] propose to use acoustic control for above mentioned algorithms, based on amplitudefrequency response of natural oscillations of objects.

Previously in $[12,18]$ an assumption was made and partially confirmed, that as an informative source of 
diagnostic signal it is necessary to employ amplitudefrequency response of object's own oscillations within the acoustic range.

Among the methods of acoustic control the following are distinguished: the active ones, using radiation and reception of acoustic signals; and the passive ones, based only on reception of acoustic signals [11].

Acoustic control methods are based on interaction of elastic oscillations of controlled products with waves of wide frequency range $[13,16]$. For non-destructive testing of multilayer structures these methods are most widely used. The main of them are the low-frequency methods, the ultrasonic method of exposure and, to a lesser extent, the method of reverberation and the acoustic and topographic method, although the possibilities of which are not fully disclosed. Obviously, the main problem lies in methodology and is applied to mathematical apparatus for processing of acoustic signals. Therefore, in this work, a method of acoustic analysis for mechanisms of robotic machine tools is proposed, as well as further processing of data by means of neural networks.

\section{MATERIALS AND METHODS}

Given the special importance of the issue, the authors of the article offer a comprehensive approach, in which the processes of control and analysis are a procedure for creating a reference model of controlling an object and keeping this model current during the technological operation. The basis of this approach is the acoustic signal spectrum, reflected from the elements of the technological system and the system of its transformation (Fig. 5).

The basis for creation of a reference model is the hypothesis on the informative capabilities of the acoustic signal spectrum as a source of data about the properties and parameters of an object. As shown in [10, 12], the spectrum of eigen-damaged vibrations of an object is the most informative in relation to various properties and parameters of an object. However, informative capabilities of the acoustic signal spectrum for analysis are greatly expanded by excitation of the spectra of forced oscillations by "white noise", emitted by transmitter over the test range.

As for adopted designations: W (f) - is the signal of the object's excitation by the "white noise"; R [W (f)] - is the reaction of the object to excitation by the "white noise"; $x_{k}$, $\mathrm{x}_{1} \ldots, \mathrm{x}_{\mathrm{r}} \ldots-$ are properties and parameters of the object (configuration, velocity, deformation, effort, strain, acceleration, temperature, etc.) $\mathrm{R}[\mathrm{W}(\mathrm{f})]=\mathrm{F}\left\{\mathrm{x}_{\mathrm{k}}, \mathrm{x}_{1} \mathrm{x}_{\mathrm{r}} \ldots\right\}$.

The task of analysis and creation of a reference model of an object is to determine the object's properties and parameters $x_{k}, x_{i} \ldots x_{r} \ldots$ by response $R[W(f)]$ (Fig. 6).

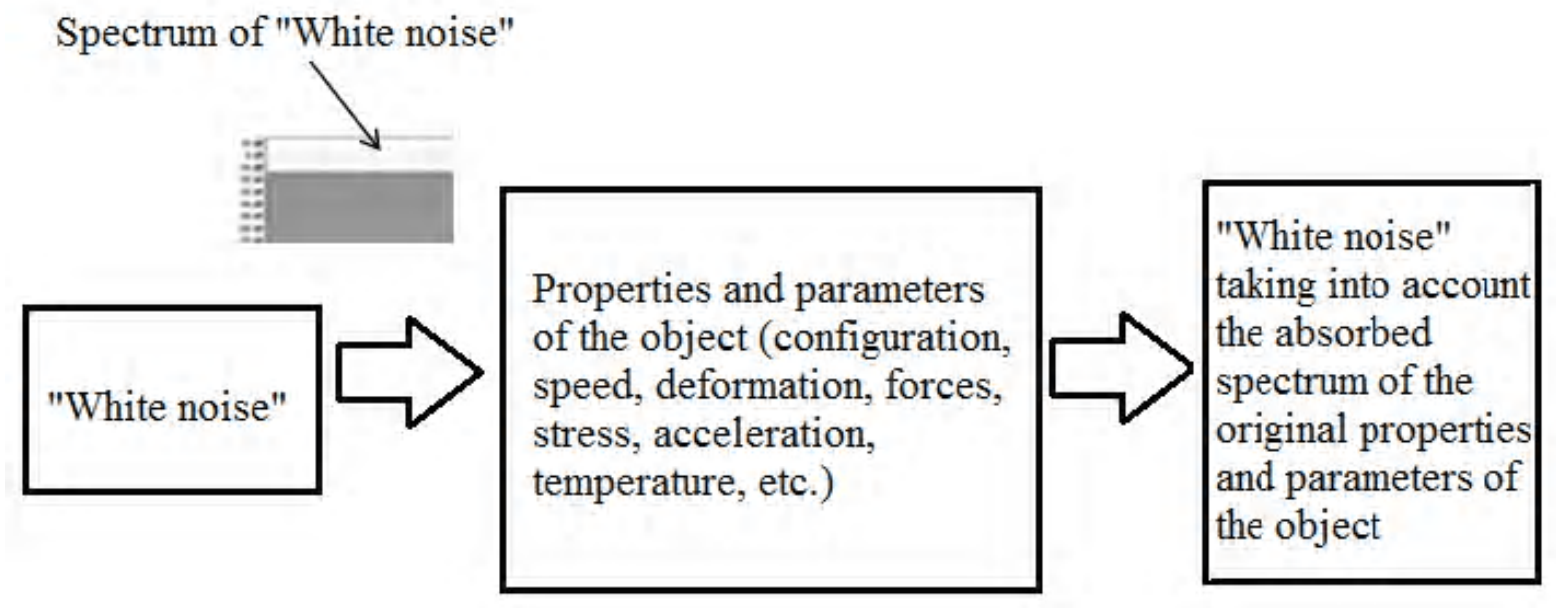

Figure 5 - Structural diagram of creation of a reference model of a mobile robotic machine tool

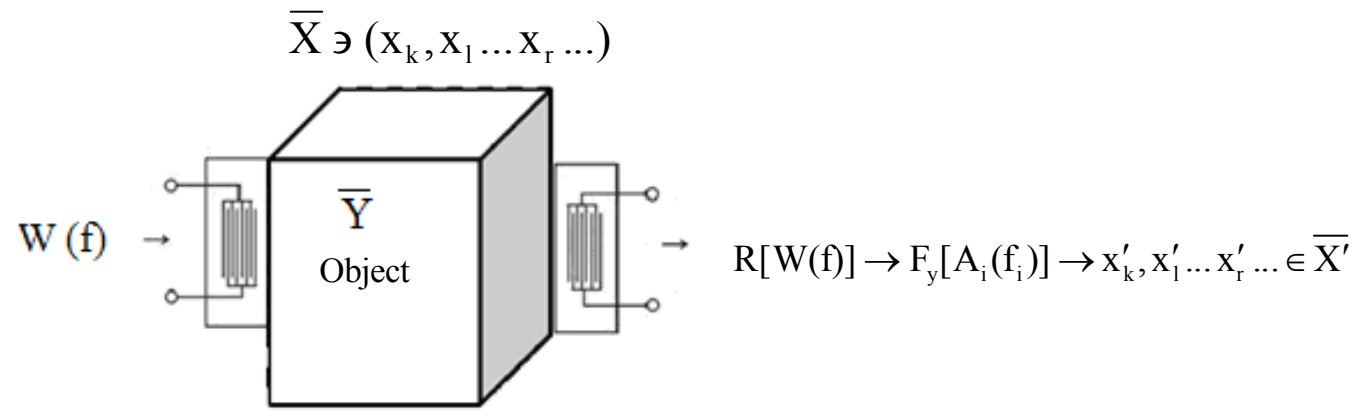

Transmitter

Sensor

Figure 6 - Information model for determining properties and parameters of an object 


\section{Object}

$$
\mathrm{W}(\mathrm{f}) \rightarrow \text { Object } \rightarrow \mathrm{R}[\mathrm{W}(\mathrm{f})] \rightarrow \mathrm{F}_{\mathrm{y}}\left[\mathrm{A}_{\mathrm{i}}\left(\mathrm{f}_{\mathrm{i}}\right)\right] \rightarrow \overline{\mathrm{X}^{\prime}} .
$$

Transmitter and receiver of the device for diagnostics are reversible piezoelectric elements, where signals are emitted (transmitter) and received (sensor). Since the analysis of an object is carried out relative to the reference signal of the "white noise", this approach permits to normalize initial diagnostic signals with respect to the reference signal.

Each dimension is maximally protected against accidental signal fluctuations. This is achieved by the fact that at each implementation of the elements of the experiment plan, the measurements are averaged over a cycle of 100 successive spectral scans with spectral discreteness of 178.3 from 0 to $20.000 \mathrm{~Hz}$. Owing to the full factor experiment, a randomized combination of factors was employed to create a database, where the factors are the coordinates of positioning of the actuator of the experimental stand.

Acoustic spectrum of response, representing the sum of excited, absorbed and reflected acoustic waves, can be processed by deep neural networks. The result of such processing is a model that integrates the features of multilayer perceptrons and Kohonen Maps. Such an association is possible by virtue of neural networks of cascade configuration and modified neural element.

NeuroPro software package grants an opportunity to apply the resulting model for prognostication of properties and parameters of an object by amplitude and frequency characteristics and thereby ensure functioning of the reference model, which is applied for intelligent control of a robotic machine tool.

After processing of information on positioning in each of the characteristic positions of the executive element, a reference model is obtained, which allows adjusting the coordinates of displacements during processing or assembly by robotic machine tools.

For the research the algorithm of fast calculation of discrete Fourier Transform using the FFT analyzer with digital audio signal input is employed. The analyzer selects successive intervals ("windows") from the signal, by which the spectrum is calculated, which is displayed in the form of a graph of amplitude-frequency dependency (Fig. 7).

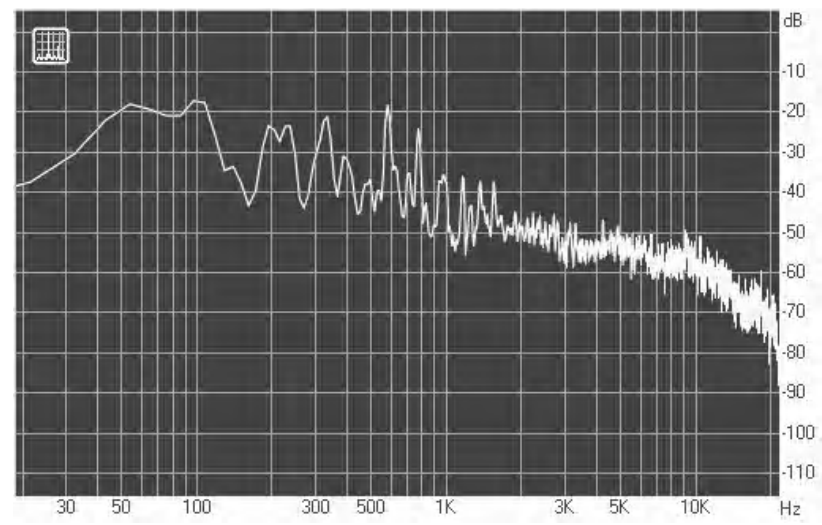

Figure 7 - Display of FFT Analyzer
Similarly to band analyzers, a logarithmic scale is usually employed for the axes of frequency and amplitude. But due to the linear positioning of FFT bands, frequency spectrum may not be sufficiently detailed at low frequencies or excessively oscillate at higher frequencies.

The horizontal line of FFT analyzer displays white noise, which is of equal energy in equal linear frequency intervals.

Parameter $N$ is the number of analyzed signal responses, and it is crucial for the spectrum type. The larger $N$, the denser is the frequency grid, by which FFT decomposes the signal, and the more frequency details are visible on the spectrum.

Longer signal areas are analyzed for higher frequency resolution. If the signal within the FFT window changes its properties, the spectrum displays averaged signal information from entire window interval.

To analyze rapid changes in the signal, the length of the window $\mathrm{N}$ is assigned a small one. In time the resolution of analysis increases, but frequency decreases. Thus, the resolution of frequency analysis is inversely proportional to the resolution of time, which can be explained by relationship of uncertainty.

In order to create an informative spectrum of an acoustic signal, a hypothesis about its informational content was accepted in case of impact on an object by the influence of "white noise", which, along with detection of active informational frequencies of the spectrum, allows forming single initial conditions during the process of analysis.

Construction of a neural network's reference model for analysis of current characteristics of an object opens with the choice of the analyzed characteristics of an object, determined by the control tasks:

- increase of the accuracy of positioning of the actuator of an object;

- provision of dynamic adjustment of the actuator;

- optimization of the displacement trajectories of the operating actuator.

Solution of these tasks is aimed at improvement of the quality and productivity of technological machines and processes.

\section{EXPERIMENTS}

Equipment for experimental research:

- an experimental stand in the form of a delta mechanism, which is a group of mechanisms based on parallel kinematics, equipped with a system of numerical software control based on the MEGA 2650 circuit, which provides control programming of the stand using G-codes;

- two sound cards installed on two computers running Windows XP operating system;

- piezoelectric transmitter and sensor.

- an amplifier of the "white noise" signal excitation, 2 watts of power.

Software:

- computer package Spectrolab;

- computer package NeuroPro-0.25;

- computer package Statistica 10.

The plan of the experiments supposed to study the relationship between the parameters of the spectrum of the acoustic signal with a given discretion, disturbed by excited 
influence in the form of "white noise". The authors put forward an assumption about a possibility of analysis of characteristics of investigated objects being invariant with respect to the errors made by the hardware part of the diagnostic system. This assumption is based on the fact that the diagnostic signal possesses initial values of the acoustic spectrum formed by the "white noise" by the same information channels and the same means as the main excited diagnostic signal.

Each of measurements $n$ possesses maximum protection against accidental signal fluctuations. This is achieved by the fact that at each implementation of the elements from the experiment plan, the measurements were averaged over a cycle of 100 successive scans of spectrum with spectral discreteness of 178.3 from 0 to $20,000 \mathrm{~Hz}$. A full-factor experiment with randomization of combinations of factors allowed formation of a database, where the factors were the positioning coordinates of the actuator of the experimental stand $\left(x_{i}, y_{i}, z_{i}\right), i=1 \ldots n$. An example of $a$ fragment of such a database for experimental positions is presented in Table 1 .

An example of acoustic spectrum of diagnostic signal for identifying the positioning of the actuator of the experimental stand is presented in Fig. 8.

\section{RESULTS}

On the experimental basis there were constructed neural network diagnostic models:

- configuration of the mechanism;

- geometric parameters of the mechanism while running motor-spindle;

- dynamics of displacement of nodes of the mechanism of the experimental stand with variable velocity and load on the drive;

- temperature changes of the object.

The created neural network models were tested for adequacy by Fisher's criterion. The results of assessment of these models are presented in Table 2.

Table 1 - Amplitudes of acoustic spectrum by its discrete

\begin{tabular}{|c|c|c|c|c|c|c|c|c|c|}
\hline \multirow{2}{*}{ No. } & \multicolumn{3}{|c|}{ Inputs: positioning coordinates, $\mathrm{mm}$} & \multicolumn{6}{|c|}{ Outputs: amplitude of acoustic spectrum, decibel, according to its discrete, $\mathrm{Hz}$} \\
\hline & $\mathrm{X}, \mathrm{mm}$ & $\mathrm{Y}, \mathrm{mm}$ & $\mathrm{Z}, \mathrm{mm}$ & 172,3 & 344,6 & 516,9 & $\ldots$ & 21882,1 & 22054,4 \\
\hline 1 & -52 & -30 & 5 & $-29,9$ & $-29,76$ & $-46,87$ & $\ldots$ & $-73,68$ & $-81,32$ \\
\hline 2 & 52 & -30 & 5 & $-32,3$ & $-31,94$ & $-46,98$ & $\ldots$ & $-75,34$ & $-83,49$ \\
\hline 3 & 0 & -60 & 5 & $-34,49$ & $-33,72$ & $-45,56$ & $\ldots$ & $-75,61$ & $-83,99$ \\
\hline 4 & 0 & 0 & 5 & $-36,68$ & $-36,11$ & $-48,39$ & $\ldots$ & $-76,12$ & $-84,93$ \\
\hline$\ldots$ & $\ldots$ & $\ldots$ & $\ldots$ & $\ldots$ & $\ldots$ & $\ldots$ & $\ldots$ & $\ldots$ & $\ldots$ \\
\hline$n-3$ & -52 & -30 & 250 & $-54,24$ & $-48,78$ & $-49,53$ & $\ldots$ & $-75,75$ & $-83,77$ \\
\hline $\mathrm{n}-2$ & 52 & -30 & 250 & $-53,57$ & $-48,33$ & $-48,57$ & $\ldots$ & $-76,55$ & $-84,44$ \\
\hline $\mathrm{n}-1$ & 0 & -60 & 250 & $-55,13$ & $-48,41$ & $-48,71$ & $\ldots$ & $-76,27$ & $-84,16$ \\
\hline $\mathrm{n}$ & 0 & 0 & 250 & $-54,31$ & $-49,35$ & $-50,21$ & $\ldots$ & $-75,86$ & $-84,02$ \\
\hline
\end{tabular}

Frequancy, $f, \mathrm{~Hz}$

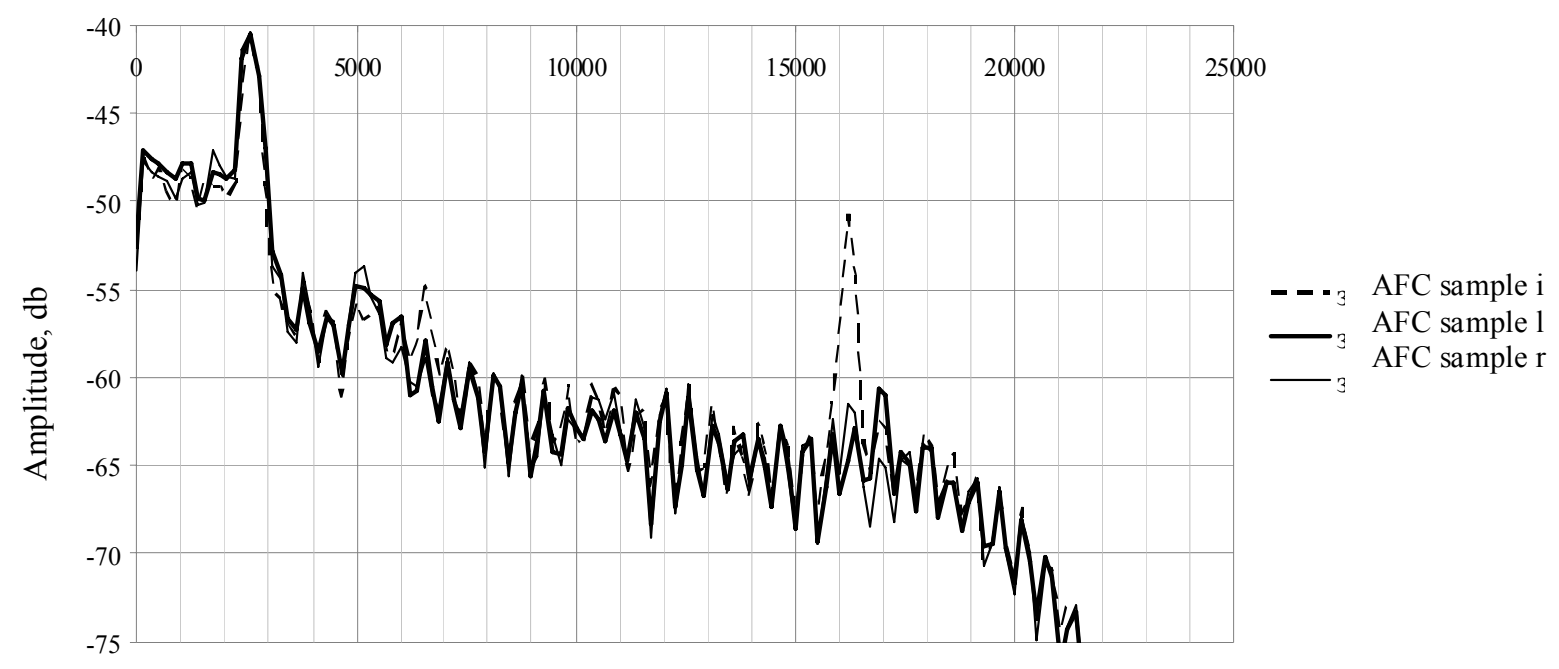

Figure 8 - Examples of spectra of acoustic signals for positioning coordinates of the actuator of an experimental stand 


\section{DISCUSSION}

While training a neural network an input data sample (frequency response parameters) was formed, i.e. the input data relative to the positioning. Within the framework of these input data a neural network model was constructed, for which it was assumed in the very beginning that it would allow establishing a relationship between frequency response and coordinates of the position of the actuator of a robotic machine tool. Yet these data are obtained due to measurements, so there occurs an error (hence there is a statistical probability). These data were obtained before the experiment.

In general, this approach justifies feasibility of implementation of the concept of deep neural network (Fig. 9).

Adequacy of the models is confirmed by repeated excess of calculated value of Fisher's criterion over its table value for a given error probability for the input models - frequency ranges of the acoustic spectrum, constructed for the tuple time of the initial data.
The obtained results of the study confirm the provisions outlined in [12], where the authors state that control of the executive motions of technological machines with mechanisms of parallel structure is a complex task, a solution of which can be done on the basis of solving kinematic problems and dynamics of actuators. As a result, conditions can be created for precise positioning of operating elements of actuators at optimal speeds and accelerations of their displacements on a given trajectory. For these purposes, control systems should be equipped with informative systems of object identification. To confirmthis, the results of experimental studies are proposed, which provide a basis for establishment of diagnostic systems of kinematics and dynamics of a mechanism, on the basis of which mobile robotic machine tools are created for application in reconfigurable production systems of mechanical processing.

\section{CONCLUSIONS}

During the research an actual task of increasing the accuracy of positioning of actuators of robotic machine tools has been solved.

Table 2 - Verification of mathematical models, constructed according to experimental data, for adequacy by Fisher's criterion under conditions $\mathrm{F}_{\text {table }}<<\mathrm{F}_{\text {est }}$

\begin{tabular}{|c|c|c|c|c|c|}
\hline $\begin{array}{c}\text { Object of the } \\
\text { experiment }\end{array}$ & \multicolumn{2}{|c|}{ Input coordinates $\mathrm{x}_{\mathrm{i}}, \mathrm{y}_{\mathrm{i}}, \mathrm{z}_{\mathrm{i}}$} & $\delta$ & $\mathrm{F}_{\text {table }}$ & $\mathrm{F}_{\text {est. }}$ \\
\hline \multirow{6}{*}{$\begin{array}{l}\text { Configuration of the } \\
\text { mechanism }\end{array}$} & \multicolumn{2}{|c|}{$\mathrm{x}_{0}=-75,-50,-25,0,25,50,75$} & 0.01 & 2.67 & $8.6 \times 10^{7}$ \\
\hline & \multirow{2}{*}{\multicolumn{2}{|c|}{$\begin{array}{l}y_{0}=-75,-50,-25,0,25,50,75 \\
z_{0}=-75,-50,-25,0,25,50,75\end{array}$}} & 0.01 & 2.66 & $4.5 \times 10^{7}$ \\
\hline & & & 0.01 & 2.66 & $1.6 \times 10^{8}$ \\
\hline & \multicolumn{2}{|c|}{$\mathrm{x}_{1}=-75,-50,-25,0,25,50,75$} & 0.01 & 2.60 & $9.6 \times 10^{3}$ \\
\hline & \multicolumn{2}{|c|}{$y_{1}=-75,-50,-25,0,25,50,75$} & 0.01 & 2.60 & $3.1 \times 10^{4}$ \\
\hline & \multicolumn{2}{|c|}{$z_{1}=-75,-50,-25,0,25,50,75$} & 0.01 & 2.60 & $2.1 \times 10^{4}$ \\
\hline \multirow{3}{*}{$\begin{array}{l}\text { Configuration with } \\
\text { runnung motor-spindle }\end{array}$} & \multicolumn{2}{|c|}{$x_{0}=-75,-50,-25,0,25,50,75$} & 0.01 & 2.63 & $1.4 \times 10^{3}$ \\
\hline & \multirow{2}{*}{\multicolumn{2}{|c|}{$\begin{array}{l}y_{0}=-75,-50,-25,0,25,50,75 \\
z_{0}=-75,-50,-25,0,25,50,75\end{array}$}} & 0.01 & 2.60 & $2.9 \times 10^{8}$ \\
\hline & & & 0.01 & 2.59 & $1.8 \times 10^{7}$ \\
\hline \multirow{8}{*}{$\begin{array}{l}\text { Trajectory of } \\
\text { displacement with } \\
\text { variable velocity and } \\
\text { load on the drive }\end{array}$} & \multirow{2}{*}{$\mathrm{X}_{0}>\mathrm{X}_{1}$} & $\mathrm{X}_{0}$ & 0.01 & 2.60 & $5,9 \times 10^{2}$ \\
\hline & & $\mathrm{X}_{1}$ & 0.01 & 2.60 & $6,5 \times 10^{2}$ \\
\hline & \multirow{2}{*}{$\mathrm{Y}_{0}>\mathrm{Y}_{1}$} & $\mathrm{Y}_{0}$ & 0.01 & 2.60 & $6,7 \times 10^{2}$ \\
\hline & & $\mathrm{Y}_{1}$ & 0.01 & 2.60 & $6,7 \times 10^{2}$ \\
\hline & \multirow{2}{*}{$\mathrm{Z}_{0}>\mathrm{Z}_{1}$} & $Z_{0}$ & 0.1 & 2.60 & $8,8 \times 10^{2}$ \\
\hline & & $\mathrm{Z}_{1}$ & 0.1 & 2.60 & $8,8 \times 10^{2}$ \\
\hline & \multicolumn{2}{|c|}{ Displacement velocity } & 0.01 & 2.60 & $4.7 \times 10^{2}$ \\
\hline & \multicolumn{2}{|c|}{ Actuator's weight } & 0.01 & 2.60 & $3.5 \times 10^{2}$ \\
\hline \multirow{2}{*}{$\begin{array}{l}\text { Changes in sample } \\
\text { temperature within } \\
\text { limits } 25 \ldots 90 \mathrm{C}^{0}\end{array}$} & \multicolumn{2}{|c|}{ Sample 1} & $0.1 \mathrm{C}^{0}$ & 3.17 & $3.7 \times 10^{2}$ \\
\hline & \multicolumn{2}{|c|}{ Sample 2} & $0.1 \mathrm{C}^{0}$ & 3.05 & $6.9 \times 10^{2}$ \\
\hline
\end{tabular}

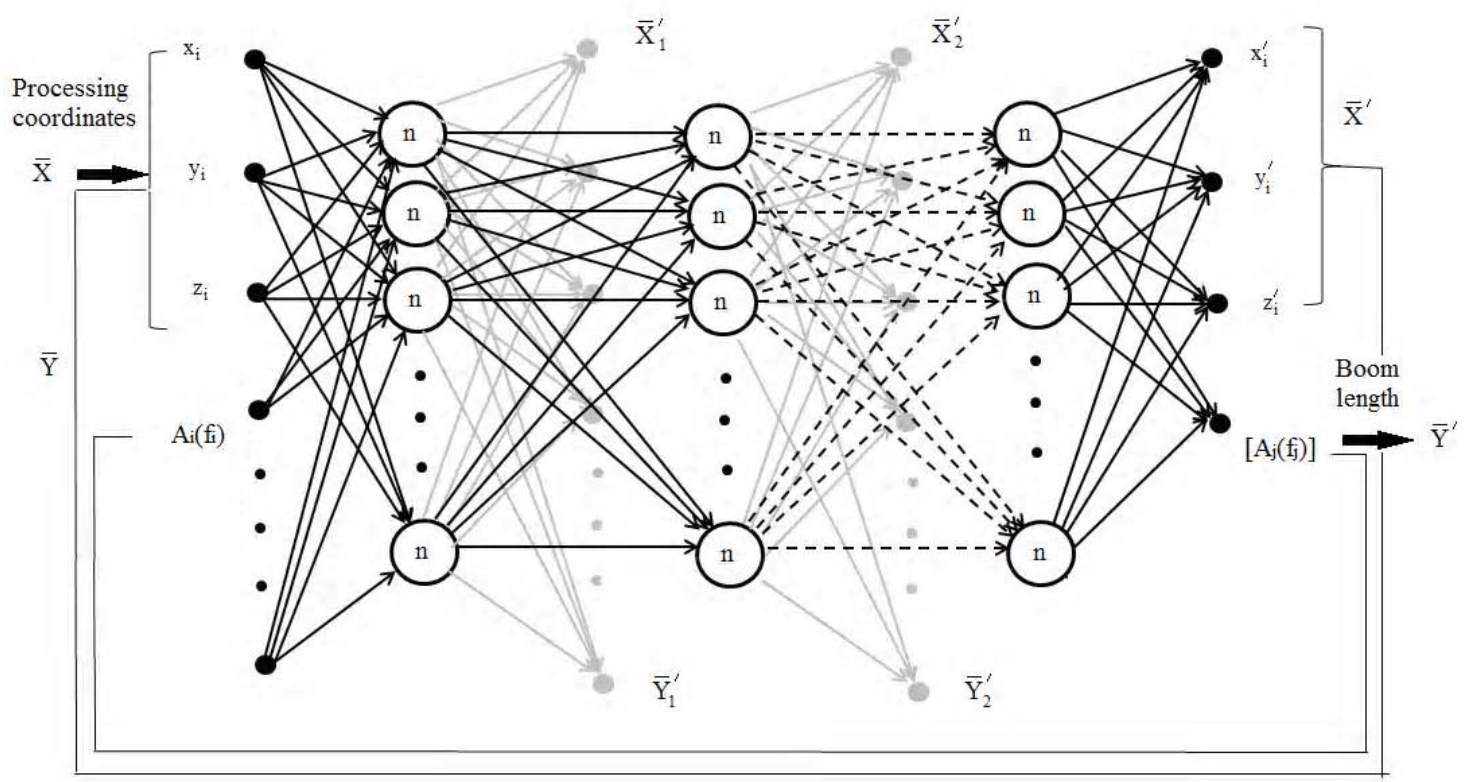

Figure 9 - Deep neural network scheme 
The scientific novelty of the work consists in the method of identification and control of a mobile robotic machine tool on the basis of amplitude-frequency response, reflecting absorption of acoustic wave with further processing of information by deep neural networks of cascade architecture.

A new approach is proposed to the control of complex technological machines, such as machines with mechanisms of parallel structure for increasing the accuracy of positioning of actuators, ensuring their dynamic adjustment and optimization of trajectories of displacement of operating elements of the equipment (cutting tools).

Practical value of the obtained results consists in the development of the method of acoustic analysis for mechanisms of robotic machine tools. This allows to expand the range of opportunities for the improvement of the accuracy and performance of their performance.

Prospects for further research may consist in creation of hardware for controlling complex technological machines, such as machines with mechanisms based on parallel kinematics to improve the accuracy of the positioning of actuators, ensuring their dynamic adjustment and optimizing the trajectories of displacements of operating elements of the equipment.

\section{ACKNOWLEDGMENTS}

The work has been carried out within the framework of the State Budget Scientific Research of the Donbas State Engineering Academy "Development of neural network models for accelerated technological devising of production of new competitive products" (State Registration Number 0116U003615).

\section{REFERENCES}

1. Kovalevskyy S. V. Acoustic Monitoring with Neural Network Analysis / S. V. Kovalevskyy, O. S. Kovalevska // American Journal of Neural Networks and Applications. - 2015. - Vol. 1, No. 2. P. 39-42. DOI: 10.11648/j.ajnna.20150102.12

2. Tyurin Yu. N. Electric heating using a liquid electrode / Y. N. Tyurin, A. D. Pogrebnjak // Surface and Coatings Technology. 2001. - P. 293-299.

3. Hohmann M. Production methods and applications for highquaIity metaI powders and sprayformed products / M. Hohmann, G. Brooks, C. Spiegelhauer. - Produktionsmethoden und Anwendungen fur qualitativ hochwertige Metallpulver und spruhkompaktierte Halbzeuge. Stahl und Eisen, 2005. - 258 p.

4. Yasa E. Application of laser re-melting on Selective laser melting parts. Catholic University of Leuven, Dept. of Mech. Eng, Heverlee, Belgium. Advances in Production Engineering / E. Yasa, J. Kruth // Management. - 6. - 2011. - P. 259-270.

5. David L. A Brief History of Additive / L. David Bourella, J. Joseph Beaman, Jr. a, Ming C. Leub and W. David Rosenc. - Manufacturing and the 2009 Roadmap for Additive Manufacturing: Looking Back and Looking Ahead. RapidTech, 2009. - 328 p.
6. Dutta B. Additive Manufacturing by Direct Metal Deposition / B. Dutta et. al. // Advanced materials \& processes. - May. 2011. - P. 33-36.

7. Fngelo H. C. Powder Metalurge: Science, technology and application / H. C. Fngelo, R. Subramanian. - New Dehli, 2009. - 128 p.

8. Kruglov I. A. Neural networks modeling of multivariable vector functions in ill-posed approximation problems / I. A. Kruglov, O. A. Mishulina // Journal of Computer and System Sciences International, 2013. - Vol. 52. No. 4. - P. 503-518.

9. Ковалевский С. В. Акустический контроль размеров и показателей шероховатости поверхностей деталей с применением нейросетевых моделей / С. В. Ковалевский, Е. С. Ковалевская, А. И. Нагиева // Нейросітьові технології та їх застосування : збірник праць міжнародної наукової конференції. - Краматорськ : ДДМА, 2014. - С. 24-35.

10. Ковалевский С. В. Развитие методов акустической диагностики в машиностроении : монографія / С. В. Ковалевский, Е. С. Ковалевская, В. И. Тулупов. - Краматорск : ДГМА, 2014. - 91 с.

11. Математические основы обработки сигналов. Практикум : учебное пособие / О. С. Вадутов ; Томский политехнический университет. - 3-е изд., испр. и доп. - Томск : Изд-во Томского политехнического университета, 2014. - 102 с.

12.Акустическая диагностика статических и динамических свойств механизмов с параллельной кинематикой // Комплексне забезпечення якості технологічних процесів та систем (КЗЯТПС - 2017): матеріали тез доповідей VII міжнародної науково-практичної конференції (м. Чернігів, 24-27 квіт. 2017 р.) : у 2-х т. / Чернігівський національний технологічний університет [та ін.]; відп. за вип.: Єрошенко Андрій Михайлович [та ін.]. - Чернігів : ЧНТУ, 2017. - Т. 1. - С. 59-60.

13. Осипов Л. А. Обработка сигналов на цифровых процессорах Линейно-аппроксимирующий метод / Л. А. Осипов. - М. : Горячая линия-Телеком, 2001. - 114 с.

14. Селиванов С. Г. Системотехника инновационной подготовки производства в машиностроении / С. Г. Селиванов, М. Б. Гузаиров. - М. : Машиностроение, 2012. - 568 с.

15. Смирнов В. А. Кинетостатическое моделирование энергоэффективного управления оборудованием с параллельной кинематикой / В. А Смирнов // Вестник ЮУрГУ. Серия «Машиностроение». - 2010. - Вып. 16, № 29. - С. 65-71.

16. Христофоров А. В. Методы анализа спектра сигнала : учебнометодическое пособие к специальному лабораторному практикуму для студентов старших курсов и магистрантов кафедр радиофизического направления / А. В. Христофоров. - Казань, 2004. - 21 c.

17. Жук А. Я. Техническая диагностика. Контроль и прогнозирование: монография / [А. Я. Жук, Г. П. Малышев, Н. К. Желябина, О. М. Клевцов]. - Запорожье : Издательство Запорожской государственной инженерной академии, 2008. - 500 с.

18. Діагностика технологічних систем і виробів машинобудування (з використанням нейромережевого підходу) : монографія / С. В. Ковалевський, О. С. Ковалевська, С. О. Коржов, А. О. Кошевой ; за заг. ред. д.т.н., проф. С. В. Ковалевського. Краматорськ : ДДМА, 2016. - 186 с.

Article was submitted 06.02.2018 After revision 26.02.2018.

Ковалевська О. С. ${ }^{1}$, Ковалевський С. В. ${ }^{2}$

${ }^{1}$ Канд. техн. наук, доцент, доцент кафедри технології машинобудування Донбаської державної машинобудівної академії, Краматорськ, Україна

${ }^{2}$ Д-р техн. наук, професор, заведующий кафедри технології машинобудування Донбаської державної машинобудівної академії, Краматорськ, Україна

\section{ЗАСТОСУВАННЯ АКУСТИЧНОГО АНАЛІЗУ В СИСТЕМАХ УПРАВЛІННЯ ВЕРСТАТІВ-РОБОТІВ}

Актуальність. Розглянуто задачу управління складними технологічними машинами, такими, як верстати 3 механізмами на основі кінематики $з$ паралельною структурою для підвищення точності позиціонування виконавчих механізмів, забезпечення їх динамічної настройки і оптимізації траєкторій переміщень робочих органів обладнання (ріжучого інструменту, складального або контролюючого інструменту). Об'єктом дослідження є модель робочої зони мобільного верстата-робота.

Мета роботи - створення концепції управління мобільним верстатом-роботом із застосуванням акустичного контролю на основі еталонної моделі на глибоких нейронних мережах.

Метод. Запропоновано метод ідентифікації та управління мобільним верстатом - роботом 3 використанням спектрального опису поглинання акустичної хвилі з подальшою обробкою отриманій інформації. Метод дозволяє визначати точність позиціонування виконавчих механізмів, проводити ї динамічну настройку і оптимізацію траєкторій переміщень робочих органів обладнання. Розроблено методику акустичної діагностики забезпечення точності механічної обробки на верстатах 3 паралельною кінематикою. 
Результати. Побудована нейромережева еталонна модель, що дозволяє діагностувати поточну характеристики стану об'єктів в різних умовах, а саме, конфігурацію механізму, геометричні параметри механізму при працюючому мотор-шпинделі, динаміку переміщення вузлів механізму експериментального стенду зі змінною швидкістю і навантаженням на привід, зміни температури об'єкта. Розроблені нейромережні моделі були перевірені на адекватність.

Висновки. Проведені експерименти по дослідженню залежності між параметрами спектра акустичного сигналу із заданою дискретністю, порушеної збудливим впливом у вигляді «білого шуму», підтвердили працездатність даного підходу. Перспективи подальших досліджень можуть полягати в створенні методів оптимального управління складними технологічними машинами для підвищення точності позиціонування виконавчих механізмів, удосконалення їх динамічної настройки.

Ключові слова: акустична діагностика, верстат-робот, нейронні мережі, еталонна модель.

Ковалевская Е. С. ${ }^{1}$, Ковалевский С. В. ${ }^{2}$

${ }^{1}$ Канд. техн. наук, доцент, доцент кафедры технологии машиностроения Донбасской государственной машиностроительной академии, Краматорск, Украина

${ }^{2}$ Д-р техн. наук, профессор, профессор кафедры технологии машиностроения Донбасской государственной машиностроительной академии, Краматорск, Украина

ПРИМЕНЕНИЕ АКУСТИЧЕСКОГО АНАЛИЗА В СИСТЕМАХ УПРАВЛЕНИЯ СТАНКОВ-РОБОТОВ

Актуальность. Рассмотрена задача управления сложными технологическими машинами, такими, как станки с механизмами на основе кинематики с параллельной структурой для повышения точности позиционирования исполнительных механизмов, обеспечения их динамической настройки и оптимизации траекторий перемещений рабочих органов оборудования (режущего инструмента, сборочного или контролирующего инструмента). Объектом исследования является модель рабочей зоны мобильного станка-робота.

Цель работы - создание концепции управления мобильным станком-роботом с применением акустического контроля на основе эталонной модели на глубоких нейронных сетях.

Метод. Предложен метод идентификации и управления мобильным станком-роботом с использованием спектрального описания поглощения акустической волны с последующей обработкой полученной информации. Метод позволяет определять точность позиционирования исполнительных механизмов, проводить их динамическую настройку и оптимизацию траекторий перемещений рабочих органов оборудования. Разработана методика акустической диагностики обеспечения точности механической обработки на станках с параллельной кинематикой.

Результаты. Построена нейросетевая эталонная модель, позволяющая диагностировать текущие характеристики состояния объектов в различных условиях, а именно, конфигурацию механизма, геометрические параметры механизма при работающем мотор - шпинделе, динамику перемещения узлов механизма экспериментального стенда с переменной скоростью и нагрузкой на привод, изменения температуры объекта. Разработанные нейросетевые модели были проверены на адекватность.

Выводы. Проведенные эксперименты по исследованию зависимости между параметрами спектра акустического сигнала с заданной дискретностью, возбужденного воздействием в виде «белого шума», подтвердили работоспособность данного подхода. Перспективы дальнейших исследований могут заключаться в создании методов оптимального управления сложными технологическими машинами для повышения точности позиционирования исполнительных механизмов, совершенствование их динамической настройки.

Ключевые слова: акустическая диагностика, станок-робот, нейронные сети, эталонная модель.

\section{REFERENCES}

1. Kovalevskyy S. V., Kovalevska O. S. Acoustic Monitoring with Neural Network Analysis, American Journal of Neural Networks and Applications, 2015, Vol. 1, No. 2, pp. 39-42. DOI: 10.11648/ j.ajnna.20150102.12

2. Tyurin Yu. N., Pogrebnjak A. D. Electric heating using a liquid electrode, Surface and Coatings Technology, 2001, pp. 293-299.

3. Hohmann M., Brooks G., Spiegelhauer C. Production methods and applications for high-quality metaI powders and sprayformed products. Produktionsmethoden und Anwendungen fur qualitativ hochwertige Metallpulver und spruhkompaktierte Halbzeuge. Stahl und Eisen, 2005, 258 p.

4. Yasa E., Kruth J. Application of laser re-melting on Selective laser melting parts. Catholic University of Leuven, Dept. of Mech. Eng, Heverlee, Belgium. Advances in Production Engineering, Management, 6, 2011, pp. 259-270.

5. David Bourella L., Joseph Beaman J., Jr. a, Ming C. Leub and W. David Rosenc. A Brief History of Additive. Manufacturing and the 2009 Roadmap for Additive Manufacturing: Looking Back and Looking Ahead. RapidTech, 2009, 328 p.

6. Dutta B. et. al. Additive Manufacturing by Direct Metal Deposition, Advanced materials \& processes, May, 2011, pp. 33-36.

7. Fngelo H. C. Subramanian R. Powder Metalurge: Science, technology and application. New Dehli, 2009, 128 p.

8. Kruglov I. A., Mishulina O. A. Neural networks modeling of multivariable vector functions in ill-posed approximation problems, Journal of Computer and System Sciences International, 2013, Vol. 52, No. 4, pp. 503-518.

9. Kovalevskiy S. V., Kovalevskaya E. S., Nagieva A. I. Akusticheskiy kontrol razmerov i pokazateley sherohovatosti poverhnostey detaley s primeneniem neyrosetevyih modeley, NeyrositovI tehnologiyi ta yih zastosuvannya : zbirnik prats mizhnarodnoyi naukovoyi konferentsiyi. Kramatorsk, DDMA, 2014, pp. 24-35.

10.Kovalevskiy S. V., Kovalevskaya E. S., Tulupov V. I. Razvitie metodov akusticheskoy diagnostiki $\mathrm{v}$ mashinostroenii: monograflya. Kramatorsk, DGMA, 2014, 91 p.
11. Vadutov O. S. Matematicheskie osnovyi obrabotki signalov. Praktikum: uchebnoe posobie; Tomskiy politehnicheskiy universitet. 3-e izd., ispr. i dop. Tomsk, Izd-vo Tomskogo politehnicheskogo universiteta, 2014, $102 \mathrm{p}$.

12.Eroshenko AndrIy Mihaylovich Akusticheskaya diagnostika staticheskih i dinamicheskih svoystv mehanizmov s parallelnoy kinematikoy, Kompleksne zabezpechennya yakostI tehnologIchnih protsesIv ta sistem (KZYaTPS - 2017): materIali tez dopovIdey VII mizhnarodnoYi naukovo-praktichnoyi konferentsiyi (m. Chernigiv, 24-27 kvit. 2017 r.) : u 2-h t. ChernIgIvskiy natsIonalniy tehnologIchniy unIversitet [ta in.]; vidp. za vip.: [ta in.]. Chernigiv, ChNTU, 2017, Vol. 1, pp. 59-60.

13. Osipov L. A. Obrabotka signalov na tsifrovyih protsessorah. Lineyno-approksimiruyuschiy metod. Moscow, Goryachaya liniya-Telekom, 2001, $114 \mathrm{p}$.

14. Selivanov S. G., Guzairov M. B. Sistemotehnika innovatsionnoy podgotovki proizvodstva $\mathrm{V}$ mashinostroenii. Moscow, Mashinostroenie, 2012, $568 \mathrm{p}$.

15.Smirnov V. A. Kinetostaticheskoe modelirovanie energoeffektivnogo upravleniya oborudovaniem s parallelnoy kinematikoy, Vestnik YuUrGU. Seriya «Mashinostroenie», 2010, Vyp. 16, No. 29, pp. 65-71

16.Hristoforov A. V. Metodyi analiza spektra signala. Uchebnometodicheskoe posobie $\mathrm{k}$ spetsialnomu laboratornomu praktikumu dlya studentov starshih kursov i magistrantov kafedr radiofizicheskogo napravleniya. Kazan 2004, 21 p.

17. Zhuk A. Ya., Malyishev G. P., Zhelyabina N. K., Klevtsov O. M. Tehnicheskaya diagnostika. Kontrol i prognozirovanie: monografiya. Zaporozhye, Izdatelstvo Zaporozhskoy gosudarstvennoy inzhenernoy akademii, 2008, 500 p.

18. Kovalevs'kyy S. V., Kovalevs'ka O. S., Korzhov Ye. O., Koshevoy A. O.; za zah. red. d.t.n., prof. S. V. Kovalevs'koho Diahnostyka tekhnolohichnykh system i vyrobiv mashynobuduvannya ( $\mathrm{z}$ vykorystannyam neyromerezhevoho pidkhodu) : monohrafiya. Kramators'k, DDMA, 2016, 186 p. 